\title{
Selective Alterations in Ionotropic Glutamate Receptors in the Anterior Cingulate Cortex in Schizophrenia
}

Katerina Zavitsanou, Ph.D., Philip B. Ward, B.Med.Sc., Ph.D., and Xu-Feng Huang, M.D., Ph.D.

The anterior cingulate cortex is a brain area of potential importance to our understanding of the pathophysiology of schizophrenia. Previous studies suggest abnormalities in the glutamatergic neurotransmission in the anterior cingulate cortex in schizophrenia patients. In the present study we used quantitative autoradiography to investigate the binding of $\left[{ }^{3} \mathrm{H}\right] \mathrm{MK} 801,\left[{ }^{3} \mathrm{H}\right] \mathrm{L}-\alpha-$ amino-3-hydroxy-5methyl-4-isoxazole propionic acid (AMPA), and $\left[{ }^{3} H\right]$ kainate, which respectively label the N-methyl-Daspartate (NMDA), AMPA, and kainate receptors of the ionotropic glutamate receptor family, in the left anterior cingulate cortex of 10 schizophrenia patients and 10 controls, matched for age, gender, and postmortem interval.

AMPA receptor densities were higher in cortical layer II, whereas NMDA receptor densities were higher in cortical layers II-III in the anterior cingulate cortex of both control and schizophrenia group. In contrast, kainate receptors displayed the highest density in cortical layer V. [ $\left.{ }^{3} H\right] A M P A$ binding was significantly increased by $25 \%$ in layer II in the schizophrenia group as compared with the control group. Similarly, a significant $17 \%$ increase of $\left[{ }^{3} \mathrm{H}\right] \mathrm{MK} 801$ binding was observed in layers II-III in the schizophrenia group. No statistically significant difference was observed for $\left[{ }^{3} \mathrm{H}\right]$ kainate binding between the schizophrenia and control groups.

These results suggest that ionotropic glutamate receptors are differentially altered in the anterior cingulate region in schizophrenia. The increase in $\left[{ }^{3} \mathrm{H}\right] \mathrm{AMP} A$ and $\left[{ }^{3} \mathrm{H}\right] \mathrm{MK} 801$ binding in the superficial layers suggests a postsynaptic compensation for impaired glutamatergic neurotransmission in the anterior cingulate cortex in schizophrenia. The findings add to a growing body of literature that supports a dysfunction of excitatory activity in the anterior cingulate cortex in schizophrenia.

[Neuropsychopharmacology 27:826-833, 2002]

(C) 2002 American College of Neuropsychopharmacology.

Published by Elsevier Science Inc.
KEY WORDS: Cingulate cortex; Schizophrenia; NMDA; AMPA; Kainate receptors; Autoradiography

From the Neuroscience Institute of Schizophrenia and Allied Disorders (KZ, PBW), and Metabolic Research Centre, Department of Biomedical Sciences (KZ, X-FH), University of Wollongong, NSW, and School of Psychiatry, University of New South Wales, Sydney, Australia; and Schizophrenia Research Unit, South Western Sydney Area Health Service, (PBW) Liverpool, NSW, Australia.

Address correspondence to: Dr. Katerina Zavitsanou, NISAD Centre for Collaborative Human Brain Research, Department of Biomedical Science, University of Wollongong, NSW 2522, Australia. Tel.: 61-2-42214091; Fax: 61-2-42-214096; E-mail: Katerina_Zavitsanou@uow.edu.au Received December 19, 2001; revised April 1, 2002; accepted April 3, 2002.

Online publication: 4/5/02 at www.acnp.org/citations/Npp 040502279 .
Glutamate is the primary excitatory neurotransmitter in the human brain. Excitatory synaptic activity conveyed by glutamate is mediated by three pharmacologically defined subtypes of ionotropic glutamate receptors: $\mathrm{N}$-methyl-D-aspartate (NMDA), D, L- $\alpha$-amino-3-hydroxy5-methyl-4-isoxazole propionic acid (AMPA) and kainate. The NMDA receptor comprises two subunits that are coded by genes designated NR1 and NR2A-D. NonNMDA glutamate receptor subunits comprise GluR1-4, which are AMPA-preferring, and GluR5-7, KA1 and KA2, which are kainate preferring (Hollmann and Heinemann 1994).

Pharmacological and biochemical data have suggested deficiency in glutamatergic transmission in schizo- 
phrenia. Low concentrations of glutamate have been reported in cerebrospinal fluid samples from schizophrenic patients (Kim et al. 1980); however, the most convincing evidence of the glutamate hypofunction hypothesis of schizophrenia is based on the fact that phencyclidine (PCP), a psychotomimetic drug that blocks the NMDA receptor, produces a syndrome that appears similar to schizophrenia (Javitt and Zukin 1991). PCP binds to a site in the ion channel which is gated by the NMDA-type glutamate receptor (Reynolds and Miller 1990). PCP and other NMDA channel blockers, such as MK-801 and ketamine, act as a non-competitive antagonists of glutamate-mediated ion conductances. Hence, PCP psychosis is thought to be the result of reduced NMDA receptor function.

Although it is usually the NMDA receptor that is implicated in schizophrenia, disturbances of any of the glutamate receptors could result in a condition that produces the appearance of an abnormally functioning NMDA receptor. For example, NMDA receptors are blocked by magnesium at physiological concentrations, and AMPA receptor-mediated depolarization of the membrane extrudes magnesium from the NMDA receptor complex (Reynolds and Miller 1990). Therefore, a pathological change in the function of non-NMDA receptors may affect the NMDA receptor.

Given the possibility of glutamate receptor dysfunction in schizophrenia, the expression of ionotropic glutamate receptors has been studied in post-mortem brain of schizophrenia patients and abnormalities in glutamate receptors have been reported in many brain areas (reviewed by Meador-Woodruff and Healy 2000; see also Deakin and Simpson 1997). Some of these reports have not been replicated and have been done primarily in membrane preparations. These studies illustrate that the occurrence and nature of glutamate receptor abnormalities in schizophrenia can differ between brain regions.

The anterior cingulate cortex (ACC; Brodmann's area 24) is localized within a gyrus on the media surface of each hemisphere, bordering on the corpus callosum. It receives projections from the amygdala (Vogt and Pandya 1987), thalamus (Vogt et al. 1979) and hippocampus (Vogt et al. 1979; Tamminga et al. 2000), possibly excitatory in nature. Abnormalities in glutamatergic neurotransmission have been reported in the ACC in schizophrenia. Recent studies using post-mortem human ACC indicate a dramatic increase in vertical glutamatergic axons in the superficial layers of ACC in schizophrenia (Benes 2000) and imaging studies suggest impaired activation of ACC in patients with schizophrenia during performance tasks, which could be attributed to a reduced efferent glutamatergic signal from the hippocampus to ACC (see Tamminga et al. 2000 for a review). In addition, there is a growing evidence indicating abnormalities in other neurotransmit- ter systems in the ACC in schizophrenia including dopamine, GABA, and serotonin, that could contribute to an abnormal excitatory activity in this brain area (Benes 2000; Zavitsanou and Huang 2002).

Since a disturbed balance in the excitatory neurotransmission is suggested to occur in the ACC in schizophrenia, the present study has focused on the analysis of the binding of $\left[{ }^{3} \mathrm{H}\right] \mathrm{MK} 801,\left[{ }^{3} \mathrm{H}\right] \mathrm{AMPA}$ and $\left[{ }^{3} \mathrm{H}\right]$ kainate, radioligands which respectively label the NMDA, AMPA and kainate receptors of the ionotropic glutamate receptor family, in the ACC of schizophrenia using quantitative autoradiography.

\section{MATERIALS AND METHODS}

\section{Postmortem Brain Tissue}

Human brain tissue was obtained from the New South Wales Tissue Resource Centre. The use of human tissue was approved by the University of Wollongong Research Ethics Committee (Approval No. HE99/222). Cases were excluded where there was a significant history of drug or alcohol abuse (that would meet diagnostic criteria according to DSM IIIR or IV), neurologic disorder or medical illness that may influence agonal state, any abnormality on neuropathological examination, or head injury or where the post-mortem interval exceeded $48 \mathrm{~h}$. Ten cases without any documented history of psychiatric disorders and ten cases with a diagnosis of schizophrenia, matched for age, gender and postmortem interval, were used in this study.

The diagnosis of schizophrenia was confirmed after review of all available medical records. From this review a treatment summary was constructed. Two instruments designed for use with medical records were then used on the information obtained to confirm the diagnosis: The Item Group Checklist of the Schedules for Clinical Assessment in Neuropsychiatry (SCAN, Jablensky et al. 1993) and the Diagnostic Instrument for Brain Studies (DIBS, Keks et al. 1999). Eight of the cases (cases 1-8, Table 1) were diagnosed according to DSM III-R using the SCAN. Two cases $(9,10$, Table 1$)$ were diagnosed according to DSM-IV using the DIBS. Both instruments have proven reliability. The mean age of onset of schizophrenia was $24.9 \pm 5.9$ years and the mean duration of the illness was $17.2 \pm 11.9$ years. The illness subtype was undifferentiated $(\mathrm{n}=4)$, paranoid $(\mathrm{n}=4)$ or residual $(n=2)$. All subjects with schizophrenia had been treated with various forms of anti-psychotic medication over a number of years before death and, based on toxicology reports, eight out of ten cases were medicated at the time of death (Table 1).

The control cases were confirmed through extensive contact with area health hospitals, and the subject's family physician. Medical records were reviewed to exclude any history of major psychiatric disorders and, if 
Table 1. Demographic Data, Characteristics and Medication of Schizophrenia Cases and Controls.

\begin{tabular}{|c|c|c|c|c|c|}
\hline & $\begin{array}{l}\text { Age } \\
\text { (yrs) }\end{array}$ & $\begin{array}{c}\text { PMD }^{a} \\
\text { (hrs) }\end{array}$ & Gender & Cause of death & Medication at death ${ }^{b}$ \\
\hline \multicolumn{6}{|c|}{ Schizophrenia cases } \\
\hline 1 & 51 & 12 & $\mathrm{~F}$ & Congestive cardiac failure & Lithium, benzodiazepines \\
\hline 2 & 51 & 21 & M & Ischemic heart disease & Thioridazine, mesoridazine \\
\hline 3 & 27 & 27 & M & Suicide by hanging & Nil \\
\hline 4 & 67 & 5 & M & Ischemic heart disease & Thioridazine, risperdal, \\
\hline 5 & 42 & 17 & M & Cardiac arrhythmia & Clozapine \\
\hline 6 & 57 & 35.5 & M & Concequences of myocardial scarring & Thioridazine, sertraline \\
\hline 7 & 27 & 30 & M & Myocarditis & Clozapine \\
\hline 8 & 27 & 9.5 & M & Clozapine toxicity & Clozapine \\
\hline 9 & 30 & 24 & M & Suicide by carbon monoxide poisoning & Clozapine \\
\hline 10 & 44 & 35 & M & Suicide by hanging & Nil \\
\hline Mean $\pm S E$ & $42.3 \pm 4.5$ & $21.6 \pm 3.4$ & & & \\
\hline \multicolumn{6}{|l|}{ Control cases } \\
\hline 1 & 52 & 9.5 & $\mathrm{~F}$ & Ischemic heart disease & Nil \\
\hline 2 & 55 & 20 & M & Cardiac arrest & Nil \\
\hline 3 & 37 & 21 & $\mathrm{M}$ & Ischemic heart disease & Nil \\
\hline 4 & 60 & 13 & M & Acute myocardial infarction & Nil \\
\hline 5 & 38 & 13.5 & M & Atherosclerotic cardiovascular disease & Nil \\
\hline 6 & 61 & 24 & M & Ischemic heart disease & Nil \\
\hline 7 & 18 & 33 & $\mathrm{M}$ & Hypertrophic cardiomyopathy & Nil \\
\hline 8 & 37 & 11 & M & Pulmonary embolism & Nil \\
\hline 9 & 37 & 24 & M & Electrocution & Nil \\
\hline 10 & 43 & 13 & M & Thrombotic coronary artery occlusion & Nil \\
\hline Mean $\pm S E$ & $43.8 \pm 4.2$ & $18.2 \pm 2.4$ & & & \\
\hline
\end{tabular}

a PMD: post-mortem delay. ${ }^{b}$ Medication at the time of death is based on toxicology reports.

necessary to exclude possible psychopathology, discussion took place with the family physician. Brains were sliced in the coronal plane at approximately $1 \mathrm{~cm}$ thickness. Tissue blocks were taken from the left side of ACC and were immediately frozen at $-80^{\circ} \mathrm{C}$ until the assays. All assays described below were carried out blind of diagnosis.

\section{Autoradiography}

Sections of $16 \mu \mathrm{m}$ thickness were cut at $-18^{\circ} \mathrm{C}$ using a cryostat (Jung CM300, Leica), mounted onto gelatincoated slides and stored at $-20^{\circ} \mathrm{C}$ until they were used. Sections from both schizophrenia and control cases were randomly selected from levels equivalent to plates 5 and 6 of the Atlas of the Human Brain (Mai et al. 1997). Tissues from normal and schizophrenic cases were sectioned alternately to avoid a sequencing bias that might potentially be incurred during cutting and storage of the sections. All control and schizophrenic tissue sections were processed simultaneously to minimize experimental variance. For each ligand one experimental run was conducted and all subjects were included.

$\left[{ }^{3} \mathrm{H}\right]$ AMPA binding was performed as previously described (Zavitsanou et al. 1996). Briefly, all sections underwent a pre-wash for $30 \mathrm{~min}$ at $4^{\circ} \mathrm{C}$ in $50 \mathrm{mM}$ Tris$\mathrm{HCl}$ buffer (pH 7.2) containing $2.5 \mathrm{mM} \mathrm{CaCl}_{2}$. Four sec- tions per case were then incubated for $60 \mathrm{~min}$ at $4^{\circ} \mathrm{C}$ in $50 \mathrm{mM}$ Tris- $\mathrm{HCl}$ buffer $(\mathrm{pH}$ 7.2) containing $63 \mathrm{nM}$ $\left[{ }^{3} \mathrm{H}\right]$ AMPA (specific activity $48.7 \mathrm{Ci} / \mathrm{mmol}, \mathrm{NEN}, \mathrm{USA}$ ) in the presence of $2.5 \mathrm{mM} \mathrm{CaCl}_{2}$ and $100 \mathrm{mM}$ potassium thiocyanate (KSCN). Two additional sections per case were incubated with $\left[{ }^{3} \mathrm{H}\right] \mathrm{AMPA}$ in the presence of 1 $\mathrm{mM}$ glutamic acid to determine non-specific binding. After the incubation, the sections were rinsed three times in cold $50 \mathrm{mM}$ Tris- $\mathrm{HCl}$ buffer containing $2.5 \mathrm{mM}$ $\mathrm{CaCl}_{2}$ for $60 \mathrm{~s}$ and dried with warm air.

$\left[{ }^{3} \mathrm{H}\right]$ Kainate binding was performed as previously described (Zavitsanou et al. 1996) with minor modifications. Briefly, all sections underwent a pre-wash for 30 $\min$ at $4^{\circ} \mathrm{C}$ in $0.31 \mathrm{M}$ Tris-citrate buffer ( $\mathrm{pH} 7.3$ ). Four sections per case were then incubated for $2 \mathrm{~h}$ at $4^{\circ} \mathrm{C}$ in $0.31 \mathrm{M}$ Tris-citrate buffer ( $\mathrm{pH} 7.3$ ) containing $42 \mathrm{nM}$ $\left[{ }^{3} \mathrm{H}\right]$ kainate (specific activity $58 \mathrm{Ci} / \mathrm{mmol}, \mathrm{NEN}$, USA). Two additional sections per case were incubated with $\left[{ }^{3} \mathrm{H}\right]$ kainate in the presence of $1 \mathrm{mM}$ glutamic acid to determine non-specific binding. After the incubation, the sections were rinsed twice for $1 \mathrm{~min}$ each time, in cold 0.31M Tris-citrate buffer with a final dip in ice-cold $\mathrm{dH}_{2} \mathrm{O}$ and dried with warm air.

$\left[{ }^{3} \mathrm{H}\right] \mathrm{MK}-801$ binding was performed according to the method by Ekonomou and Angelatou (1999). Briefly, on the day of the experiment all slides were thawed at room temperature and air-dried. Two sections per case were then incubated in $30 \mathrm{mM} \mathrm{N}$-(2-Hydroxyethyl) pip- 
erazine-N'-2-ethane sulfonic acid (HEPES) buffer, pH7.45, containing 23nM $\left[{ }^{3} \mathrm{H}\right] \mathrm{MK}-801$ (specific activity $21.7 \mathrm{Ci} / \mathrm{mmol}$, NEN, USA), $100 \mu \mathrm{M}$ glutamate, $100 \mu \mathrm{M}$ glycine and $1 \mathrm{mM}$ EDTA for $2.5 \mathrm{~h}$ at room temperature. Two additional sections per case were incubated with $\left[{ }^{3} \mathrm{H}\right] \mathrm{MK} 801$ in the presence of $200 \mu \mathrm{M}$ ketamine to determine non-specific binding. After the incubation, the sections were washed in incubation buffer containing neither glutamate nor glycine for $40 \mathrm{~min}$, with one change of buffer at $20 \mathrm{~min}$ at $0^{\circ} \mathrm{C}$, and then dried with warm air.

After the assay, sections were exposed to $\left[{ }^{3} \mathrm{H}\right]$ sensitive film (Amersham, UK) for 16-80 days. [ $\left.{ }^{3} \mathrm{H}\right]$ Microscales from Amersham were used as standards. Autoradiographs were developed at room temperature in Ilford (Phenisol) X-ray developer (4 min) and exposed to cold tap water $(15 \mathrm{sec})$, Ilford (Hypam) X-ray fixer $(4 \mathrm{~min})$, cold tap water $(10 \mathrm{~min})$ and room temperature air to dry.

\section{Quantitative Analysis of Autoradiographic Images}

Quantification analysis of the resulting autoradiographic images was performed by using a computer assisted image analysis system (Multi Analyst, BIO-RAD, USA), connected to a GS-690 Imaging Densitometre. Optical density measurements were taken from both the proisocortical and isocortical part of Brodmann's area 24 (Zilles 1990). For the confirmation of anatomical structures, sections were stained with cresyl violet (Paxinos et al. 2000) after the development of the autoradiographs. Section images on the film were then superimposed on the stained sections and observed under an Olympus BX-50 microscope to determine the distribution of each ligand among the cortical layers.

Since the three ligands displayed different distribution among cortical layers measurements were averaged from different representative compartments of the

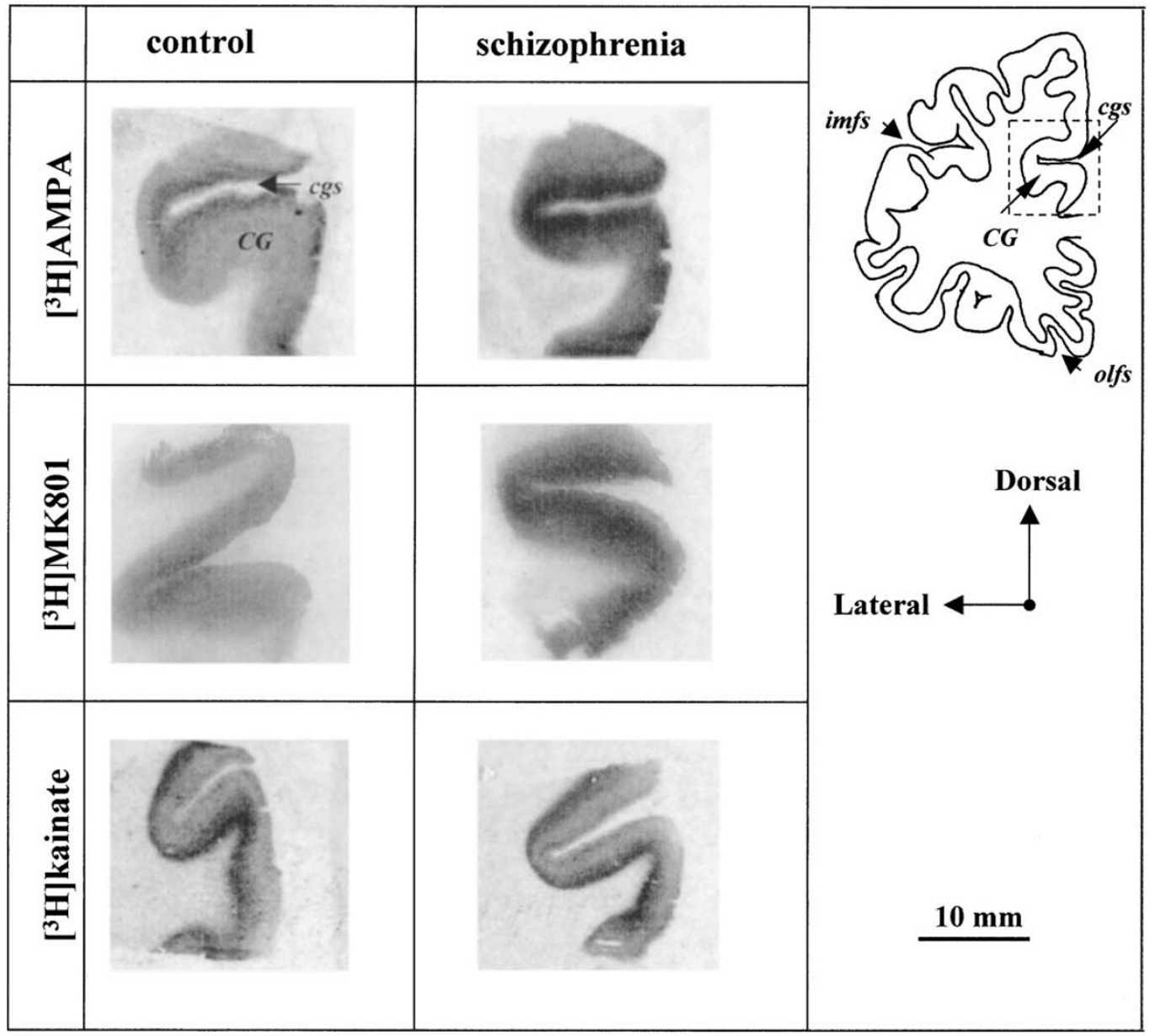

Figure 1. Digitized images of autoradiographs of $\left[{ }^{3} \mathrm{H}\right] \mathrm{AMPA},\left[{ }^{3} \mathrm{H}\right] \mathrm{MK} 801$, and $\left[{ }^{3} \mathrm{H}\right] \mathrm{kainate}$ binding in the anterior cingulate cortex of control and schizophrenia cases. Control cases with numbers 2 ([H]AMPA), $1\left(\left[{ }^{3} \mathrm{H}\right] \mathrm{MK} 801\right), 5$ ([ $\left.\left.{ }^{3} \mathrm{H}\right] \mathrm{kainate}\right)$, and schizophrenia cases with numbers 5 ([ $\left.{ }^{3} \mathrm{H}\right]$ AMPA), $6\left(\left[{ }^{3} \mathrm{H}\right] \mathrm{MK} 801\right), 4$ ([ $\left.{ }^{3} \mathrm{H}\right]$ kainate) from Table 1 are illustrated. The schematic diagram on the right indicates the location of the area analyzed. There is a statistically significant increase in $\left[{ }^{3} \mathrm{H}\right] \mathrm{AMPA}(p<$ $.01)$ and $\left[{ }^{3} \mathrm{H}\right] \mathrm{MK} 801(p<.05)$ binding in the superficial layers of anterior cingulate cortex in schizophrenia cases. CG: cingulate gyrus; cgs: cingulate sulcus; imfs: intermediate frontal sulcus; olfs: olfactory sulcus. 


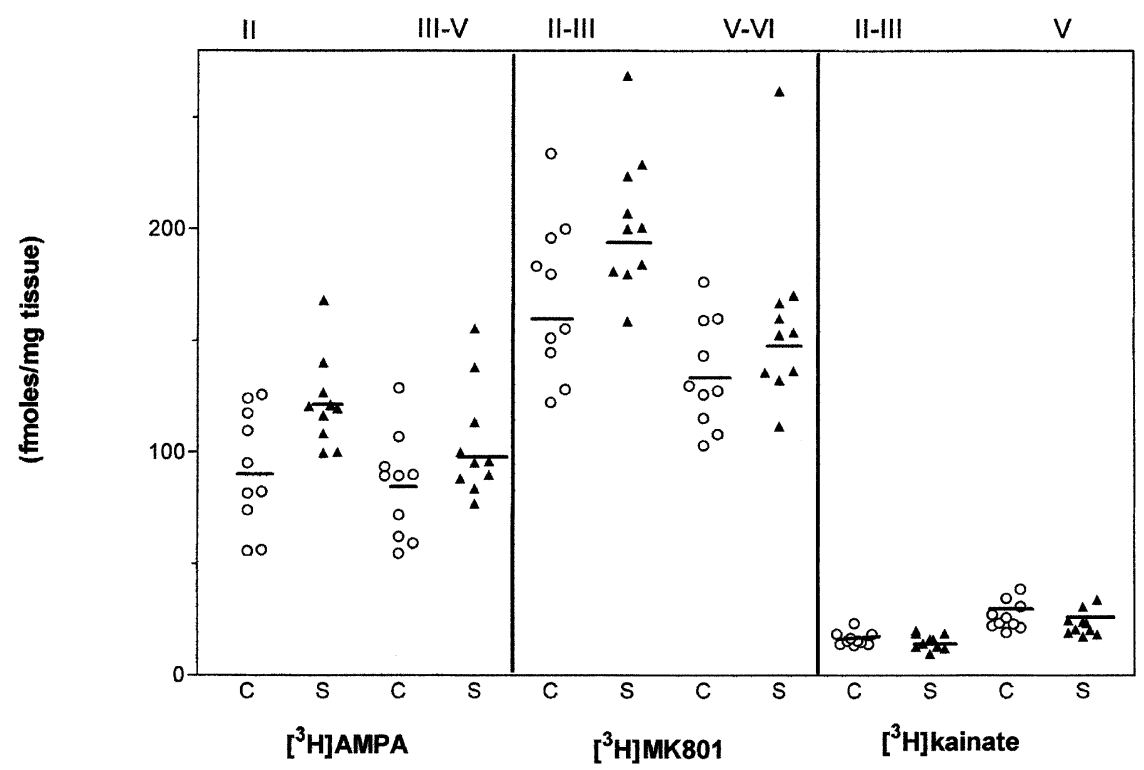

Figure 2. Scatterplot of $\left[{ }^{3} \mathrm{H}\right] \mathrm{AMPA},\left[{ }^{3} \mathrm{H}\right] \mathrm{MK} 801$, and $\left[{ }^{3} \mathrm{H}\right]$ kainate binding in the anterior cingulate cortex of control $(\mathrm{C}, \mathrm{n}=$ $10, \bigcirc)$ and schizophrenia cases $(S, n=10, \boldsymbol{\Delta})$. Horizontal bars indicate mean values. There was a statistically significant increase of $\left[{ }^{3} \mathrm{H}\right]$ AMPA $(p<.01)$ and $\left[{ }^{3} \mathrm{H}\right] \mathrm{MK} 801(p \leqslant .05)$ binding in layer II and layers III-V respectively, in the schizophrenia group.

cortical gray matter (detailed in Results section). For each compartment at least six measurements were randomly taken. Optical density was converted into fmoles $\left[{ }^{3} \mathrm{H}\right]$ ligand per $\mathrm{mg}$ tissue equivalent, according to the calibration curve obtained from the tritium standards.

Separate ANCOVA analyses, controlling for both age and post-mortem delay, were performed within each cortical compartment.

\section{RESULTS}

Autoradiographs of all three binding sites in representative schizophrenia and control cases are shown in Figure 1. Specific binding of $\left[{ }^{3} \mathrm{H}\right] \mathrm{AMPA},\left[{ }^{3} \mathrm{H}\right] \mathrm{MK}-801$ and $\left[{ }^{3} \mathrm{H}\right]$ kainate was observed in all cortical layers in the ACC. Non-specific binding was $<10 \%$ for $\left[{ }^{3} \mathrm{H}\right]$ AMPA and $\left[{ }^{3} \mathrm{H}\right] \mathrm{MK}-801$, and $<5 \%$ for $\left[{ }^{3} \mathrm{H}\right]$ kainate. $\left[{ }^{3} \mathrm{H}\right] \mathrm{MK} 801$ appears to display the highest density of binding sites followed by $\left[{ }^{3} \mathrm{H}\right]$ AMPA. $\left[{ }^{3} \mathrm{H}\right]$ Kainate displayed the lowest density of binding sites (Figure 2).

Binding sites labeled by the three ligands appeared to have differential distribution among the layers of the ACC. The principal laminar patterns of each binding site were similar in schizophrenia and control group. A higher density of $\left[{ }^{3} \mathrm{H}\right]$ AMPA binding was observed within the superficial compartment of ACC compared with the deeper layers. Inspection of Nissl staining sections indicated that this division corresponds to laminae II and III-VI respectively. In addition, higher den- sity of $\left[{ }^{3} \mathrm{H}\right] \mathrm{MK} 801$ binding sites was observed in the supragranular layers II-III of the ACC in comparison with layers V-VI. In contrast, a higher density of $\left[{ }^{3} \mathrm{H}\right]$ kainate binding sites was observed in infragranular layer $\mathrm{V}$, in comparison with the supragranular layers II-III (Figure 1).

Quantification of $\left[{ }^{3} \mathrm{H}\right]$ AMPA binding of 10 schizophrenia cases and 10 matched controls indicated that $\left[{ }^{3} \mathrm{H}\right]$ AMPA binding was greater in the ACC in schizophrenia patients than in normal controls, reaching significance in cortical layer II. More specifically, in cortical layer II we observed a $24 \%$ increase of $\left[{ }^{3} \mathrm{H}\right]$ AMPA binding in the schizophrenia group in comparison with the control group $(122.1 \pm 6.39$ versus $92.17 \pm 8.34$ fmoles $/ \mathrm{mg}$ tissue, $\mathrm{F}_{1,16}=7.13, p=.02$ ). In layers III-V, $\left[{ }^{3} \mathrm{H}\right] \mathrm{AMPA}$ binding was also increased by $18 \%$ in the schizophrenia group compared with control group; however, this increase did not reach statistical significance $(84.54 \pm 7.31$ versus $103.7 \pm 7.92 \mathrm{fmoles} / \mathrm{mg}$ tissue, $\left.\mathrm{F}_{1,16}=3.48, p=.08\right)$.

Quantification of $\left[{ }^{3} \mathrm{H}\right] \mathrm{MK} 801$ binding in cortical layers II-III of the ACC indicates that $\left[{ }^{3} \mathrm{H}\right] \mathrm{MK}-801$ binding was significantly higher by $17 \%$ in schizophrenia group as compared with control group $(203.3 \pm 9.89$ versus $168.4 \pm$ $11.64 \mathrm{fmoles} / \mathrm{mg}$ tissue, $\mathrm{F}_{1,16}=4.48, p=.05$ ). In layers $\mathrm{V}$ VI $\left[{ }^{3} \mathrm{H}\right] \mathrm{MK}-801$ binding was also increased by $15 \%$ in the schizophrenia group; however, this increase did not reach statistical significance $(158.2 \pm 12.84 \mathrm{fmoles} / \mathrm{mg}$ tissue in the schizophrenia group versus $134.8 \pm 7.66 \mathrm{fmoles} / \mathrm{mg}$ tissue in the control group, $\mathrm{F}_{1,16}=1.98, p=.18$ ). 
Quantification of $\left[{ }^{3} \mathrm{H}\right]$ kainate binding in layer $\mathrm{V}$ and layers II-III, revealed no statistically significant differences between the schizophrenia and control groups $\left(23.20 \pm 1.71\right.$ versus $26.51 \pm 1.99 \mathrm{fmoles} / \mathrm{mg}$ tissue $\mathrm{F}_{1,16}=$ $0.48, p=.49$, and $15.16 \pm 1.07$ versus $16.36 \pm 0.95$ fmoles $/ \mathrm{mg}$ tissue, $\mathrm{F}_{1,16}=1.56, p=.23$ ).

\section{DISCUSSION}

The present study investigated the binding of $\left[{ }^{3} \mathrm{H}\right] \mathrm{MK} 801,\left[{ }^{3} \mathrm{H}\right] \mathrm{AMPA}$ and $\left[{ }^{3} \mathrm{H}\right]$ kainate, radioligands which respectively label the NMDA, AMPA and kainate receptors of the ionotropic glutamate receptor family in the ACC of schizophrenia patients and controls using quantitative autoradiography. An upregulation of AMPA and NMDA receptors in supragranular layers in the ACC in schizophrenia patients was observed. No changes in kainate receptor density were observed between the schizophrenia and control groups.

The principal laminar patterns of each binding site were similar in both schizophrenia and control groups. AMPA receptor densities were higher in cortical layer II whereas NMDA receptor densities were higher in cortical layers II-III in the ACC of both control and schizophrenia groups. In contrast, kainate receptors displayed the highest density in cortical layer V. These results are in agreement with previous autoradiographic studies indicating high densities of AMPA and NMDA receptors in superficial layers and high densities of kainate receptors in deep layers of neocortex (Monaghan et al. 1984; Monaghan and Cotman 1985, 1982).

A potential confounding factor in all studies in schizophrenia is the possible effects of antipsychotic medication. Based on toxicology reports eight out of ten schizophrenia patients were under medication at the time of death. Although three schizophrenia patients were free of neuroleptics at death, their medication history indicates that they were receiving antipsychotics during life. Recent animal studies indicate reduction of $\left[{ }^{3} \mathrm{H}\right] \mathrm{MK} 801$-binding sites in the ACC after clozapine treatment (Giardino et al. 1997), whereas subchronic haloperidol and clozapine treatment significantly reduced $\left[{ }^{3} \mathrm{H}\right] \mathrm{MK} 801$ binding in the medial prefrontal cortex (Tarazi et al. 1996). It is therefore unlikely that the increases in $\left[{ }^{3} \mathrm{H}\right] \mathrm{MK} 801$ binding we observed in the schizophrenia group could be caused in these patients by the antipsychotic medication they received.

A recent study reports increases in $\left[{ }^{3} \mathrm{H}\right] \mathrm{AMPA}$ binding in the ACC in rats after clozapine treatment (Spurney et al. 1999). In addition, McCoy et al. (1998) found that haloperidol, but not clozapine, increased the density of AMPA receptors in the frontal cortex. In another study however, subchronic and chronic antipsychotic drug treatment did not alter $\left[{ }^{3} \mathrm{H}\right] \mathrm{CNQX}$ (AMPA) binding in the medial prefrontal cortex (Tarazi et al. 1996).
Although the above animal studies indicate no consensus regarding the effects of neuroleptic treatment on AMPA receptors, two recent studies reported decreased $\left[{ }^{3} \mathrm{H}\right] \mathrm{CNQX}$ (AMPA) receptor binding in the prefrontal cortex and putamen of non-schizophrenicneuroleptic treated subjects as compared with controls (Noga et al. 1997, 2001). While these studies provide some reassurance that the increased AMPA binding reported in the present study is not likely to be a medication effect, further research examining $\left[{ }^{3} \mathrm{H}\right] \mathrm{AMPA}$ binding in the ACC in non-schizophrenic neuroleptic-treated controls would help to further clarify the effects of antipsychotic medication in the ACC in schizophrenia.

Several studies, examining binding to ionotropic glutamate receptors using postmortem human tissue, have demonstrated that the occurrence and nature of glutamate receptor abnormalities in schizophrenia can differ between cortical and subcortical brain regions or even between cortical subdivisions. In the present study no changes in $\left[{ }^{3} \mathrm{H}\right]$ kainate binding were observed in the ACC between the schizophrenia and control groups. Interestingly, kainate receptor binding has been reported to be elevated in multiple cortical areas in schizophrenia (Deakin et al. 1989; Nishikawa et al. 1983) and decreased in prefrontal cortex (Meador-Woodruff et al. 2001).

The present data of increased $\left[{ }^{3} \mathrm{H}\right] \mathrm{MK}-801$ binding in the ACC in schizophrenia are in line with previous reports suggesting an upregulation of different binding sites of the NMDA receptor complex in several cortical areas in schizophrenia. Increased strychnine insensitive $\left[{ }^{3} \mathrm{H}\right]$ glycine binding has been reported in several cortical areas (Ishimaru et al. 1994), and increased [ $\left.{ }^{3} \mathrm{H}\right] \mathrm{L}-$ 689,560 binding to the glycine site of the NMDA receptor has been observed in the superior temporal gyrus of schizophrenic patients (Grimwood et al. 1999). In addition, $\left[{ }^{3} \mathrm{H}\right] \mathrm{TCP}$ binding to PCP site of the NMDA receptor was increased in the orbital frontal cortex of schizophrenic patients (Simpson et al. 1992). Unchanged $\left[{ }^{3} \mathrm{H}\right] \mathrm{MK} 801$ binding has been reported, however, in frontal and entorhinal cortices of schizophrenia patients as compared with controls (Kornhuber et al. 1989).

Our results of increased $\left[{ }^{3} \mathrm{H}\right] \mathrm{AMPA}$ binding in the ACC of schizophrenia are in agreement with increased $\left[{ }^{3} \mathrm{H}\right] \mathrm{CNQX}$ binding to AMPA receptors in layer II in the dorsolateral prefrontal cortex of schizophrenics (Noga et al. 2001). However, $\left[{ }^{3} \mathrm{H}\right]$ AMPA binding was found to be unchanged in the prefrontal cortex of schizophrenics as compared with controls (Healy et al. 1998). Moreover, a recent study employing Western blot analysis of the AMPA-preferring GluR2 and GluR3 immunoreactivity revealed no changes in these receptor subunits in the cingulate region in schizophrenia (Breese et al. 1995). It should be noted that $\left[{ }^{3} \mathrm{H}\right] \mathrm{AMPA}$ binding to AMPA receptors does not allow one to predict regulatory changes of single receptor subunits and it rather 
demonstrates an upregulation of native AMPA receptors containing the pharmacologically and functionally important AMPA binding site. In addition, methodological differences may account for this discrepancy. In our study statistically significant upregulation of AMPA receptors was observed in layer II only, whereas Breese et al. (1995) used membrane preparations from the entire cingulate cortical region.

The results of the present study are in agreement with animal studies modeling NMDA receptor hypofunction in rats, after administration of PCP. Recent studies reported heightened depolarization of cortical pyramidal neurons after application of exogenous NMDA in PCP-treated rats relative to controls (Arvanov and Wang 1999). One interpretation of these data is that prolonged reduction in glutamatergic transmission in the prefrontal cortex, caused by PCP, is associated with an upregulation of NMDA receptors, and thus the response to exogenous NMDA application is amplified. In agreement with this hypothesis increased expression of GluR1 (a subunit of the AMPA receptor) and NMDAR1 have been shown in rat prefrontal cortex after repeated exposures to PCP (see Jentsch and Roth 1999 and references therein).

One explanation of the present findings could be based on the suggestion that the ACC in schizophrenia receives an abnormally dense glutamatergic innervation, that possibly originates in the basolateral nucleus of the amygdala (Benes 2000). Increased numbers of glutamatergic afferent axons would result in increased glutamate uptake and therefore reduced synaptic levels of glutamate, sufficiently to induce a compensatory increase in postsynaptic AMPA and NMDA receptors. In agreement with this notion, reduced glutamate concentrations in cerebrospinal fluid in schizophrenia have been reported (Kim et al. 1980). However to prove such a hypothesis it is necessary to asses the function of presynaptic glutamatergic system in the ACC in schizophrenia. $\left[{ }^{3} \mathrm{H}\right]-\mathrm{D}$-aspartate binds with high affinity to the glutamate uptake site, and it is thus a marker for the integrity of pre-synaptic glutamate terminals. Importantly, increased $\left[{ }^{3} \mathrm{H}\right]-\mathrm{D}$-aspartate binding has been observed in membrane preparations of the ACC in schizophrenia although in borderline significance, which indicates that problems may be confined to a few cortical laminae (Simpson et al. 1998).

Another possible explanation of the present finding could be based on the suggestion that a primary abnormality in the hippocampus in schizophrenia is associated with a reduced efferent hippocampal glutamate signal to ACC (see Tamminga et al. 2000 for a review). It is therefore reasonable to hypothesize that a reduced efferent glutamatergic signal from the hippocampus would result in compensatory upregulation of AMPA and NMDA receptors in the ACC.

In summary, the increases in NMDA and AMPA re- ceptor densities in the superficial layers of ACC in schizophrenia suggest a dysfunction of glutamatergic neurotransmission that could theoretically alter intrinsic circuits and result in abnormal information processing. The findings add to a growing body of literature that supports abnormalities in the excitatory neurotransmission in the ACC in schizophrenia.

\section{ACKNOWLEDGMENTS}

This work was supported by the Neuroscience Institute of Schizophrenia and Allied Disorders (NISAD, http://www. nisad.org.au), utilizing infrastructure funding from New South Wales Health, and the Metabolic Research Centre, Department of Biomedical Sciences, University of Wollongong. The authors thank the New South Wales Tissue Resource Centre, which is jointly supported by NISAD and the National Heath and Medical Research Council Network for Brain Research into Mental Disorders, for providing the human brain tissue.

\section{REFERENCES}

Arvanov VL, Wang RY (1999): Clozapine, but not haloperidol, prevents the functional hyperactivity of N-methyl$\mathrm{D}$-aspartate receptors in rat cortical neurons induced by subchronic administration of phencyclidine. J Pharm Exp Therapeutics 289:1000-1006

Benes FM (2000): Emerging principles of altered neural circuitry in schizophrenia. Brain Res Rev 31:251-269

Breese CR, Freedman R, Leonard SS (1995): Glutamate receptor subtype expression in human postmortem brain tissue from schizophrenics and alcohol abusers. Brain Res 674:82-90

Deakin JF, Simpson MD (1997): A two-process theory of schizophrenia: evidence from studies in post-mortem brain. J Psychiatr Res 31:277-295

Deakin JF, Slater P, Simpson MD, Gilchrist AC, Skan WJ, Royston MC, Reynolds GP, Cross AJ (1989): Frontal cortical and left temporal glutamatergic dysfunction in schizophrenia. J Neurochem 52:1781-1786

Ekonomou A, Angelatou F (1999): Upregulation of NMDA receptors in hippocampus and cortex in the pentylenetetrazol-induced "kindling" model of epilepsy. Neurochem Res 24:1515-1522

Giardino L, Bortolotti F, Orazzo C, Pozza M, Monteleone P, Calza L, Maj M (1997): Effect of chronic clozapine administration on [3H]MK801-binding sites in the rat brain: a side-preference action in cortical areas. Brain Res 762:216-218

Grimwood S, Slater P, Deakin JF, Hutson PH (1999): NR2Bcontaining NMDA receptors are up-regulated in temporal cortex in schizophrenia. Neuroreport 10:461-465

Healy DJ, Haroutunian V, Powchik P, Davidson M, Davis KL, Watson SJ, Meador-Woodruff JH (1998): AMPA receptor binding and subunit mRNA expression in prefrontal cortex and striatum of elderly schizophrenics. Neuropsychopharmacology 19:278-286 
Hollmann M, Heinemann S (1994): Cloned glutamate receptors. Annu Rev Neurosci 17:31-108

Ishimaru M, Kurumaji A, Toru M (1994): Increases in strychnine-insensitive glycine binding sites in cerebral cortex of chronic schizophrenics: evidence for glutamate hypothesis. Biol Psychiatry 35:84-95

Jablensky A, Hugler H, von Cranach M, Kalinov K (1993): Kraepelin revisited: a reassessment and statistical analysis of dementia praecox and manic-depressive insanity in 1908. Psychol Med 23:843-858

Javitt DC, Zukin SR (1991): Recent advances in the phencyclidine model of schizophrenia. [see comments]. Am J Psychiatry 148:1301-1308

Jentsch JD, Roth RH (1999): The neuropsychopharmacology of phencyclidine: from NMDA receptor hypofunction to the dopamine hypothesis of schizophrenia. Neuropsychopharmacology 20:201-225

Keks N, Hill C, Opeskin K, Copolov D, Dean B (1999) Psychiatric diagnosis after death: the problems of accurate diagnosis. In Dean B, Hyde TM, Kleinman J (eds), The Use of CNS Autopsy Tissue in Psychiatric Research: A Practical Guide. Sydney, Gordon \& Breach Science Publishers, pp 19-37

Kim JS, Kornhuber HH, Schmid-Burgk W, Holzmuller B (1980): Low cerebrospinal fluid glutamate in schizophrenic patients and a new hypothesis on schizophrenia. Neurosci Lett 20:379-382

Kornhuber J, Mack-Burkhardt F, Riederer P, Hebenstreit GF, Reynolds GP, Andrews HB, Beckmann H (1989): $[3 \mathrm{H}] \mathrm{MK}-801$ binding sites in postmortem brain regions of schizophrenic patients. J Neural Transm 77:231-236

Mai JK, Assheuer J, Paxinos G (1997): Atlas of the Human Brain. San Diego, Academic Press

McCoy L, Cox C, Richfield EK (1998): Antipsychotic drug regulation of AMPA receptor affinity states and GluR1, GluR2 splice variant expression. Synapse 28:195-207

Meador-Woodruff JH, Davis KL, Haroutunian V (2001): Abnormal kainate receptor expression in prefrontal cortex in schizophrenia. Neuropsychopharmacology 24:545-552

Meador-Woodruff JH, Healy DJ (2000): Glutamate receptor expression in schizophrenic brain. Brain Res Brain Res Rev 31:288-294

Monaghan DT, Cotman CW (1982): The distribution of [3H]kainic acid binding sites in rat CNS as determined by autoradiography. Brain Res 252:91-100

Monaghan DT, Cotman CW (1985): Distribution of N-methylD-aspartate-sensitive L-[3H]glutamate-binding sites in rat brain. J Neurosci 5:2909-2919

Monaghan DT, Yao D, Cotman CW (1984): Distribution of [3H]AMPA binding sites in rat brain as determined by quantitative autoradiography. Brain Res 324:160-164
Nishikawa T, Takashima M, Toru M (1983): Increased $[3 \mathrm{H}]$ kainic acid binding in the prefrontal cortex in schizophrenia. Neurosci Lett 40:245-250

Noga JT, Hyde TM, Bachus SE, Herman MM, Kleinman JE (2001): AMPA receptor binding in the dorsolateral prefrontal cortex of schizophrenics and controls. Schizophr Res 48:361-363

Noga JT, Hyde TM, Herman MM, Spurney CF, Bigelow LB, Weinberger DR, Kleinman JE (1997): Glutamate receptors in the postmortem striatum of schizophrenic, suicide, and control brains. Synapse 27:168-176

Paxinos G, Huang XF, Toga A (2000): The Monkey Brain in Stereotaxic Coordinates. San Diego, Academic Press

Reynolds IJ, Miller RJ (1990): Allosteric modulation of N-methyl-D-aspartate receptors. Adv Pharmacol 21: $101-126$

Simpson MDC, Slater P, Deakin JFW (1998): Comparison of glutamate and gamma-aminobutyric acid uptake binding sites in frontal and temporal lobes in schizophrenia. Biol Psychiatry 44:423-427

Simpson MDC, Slater P, Royston MC, Deakin JFW (1992): Alterations in phencyclidine and sigma binding sites in schizophrenic brains. Schizophrenia Res 6:41-48

Spurney CF, Baca SM, Murray AM, Jaskiw GE, Kleinman JE, Hyde TM (1999): Differential effects of haloperidol and clozapine on ionotropic glutamate receptors in rats. Synapse 34:266-276

Tamminga CA, Vogel M, Gao X, Lahti AC, Holcomb HH (2000): The limbic cortex in schizophrenia: focus on the anterior cingulate. Brain Res Brain Res Rev 31:364-370

Tarazi FI, Florijn WJ, Creese I (1996): Regulation of ionotropic glutamate receptors following subchronic and chronic treatment with typical and atypical antipsychotics. Psychopharmacology (Berl) 128:371-379

Vogt BA, Pandya DN (1987): Cingulate cortex of the rhesus monkey: II. Cortical afferents. J Comp Neurol 262:271-289

Vogt BA, Rosene DL, Pandya DN (1979): Thalamic and cortical afferents differentiate anterior from posterior cingulate cortex in the monkey. Science 204:205-207

Zavitsanou K, Huang X-F (2002): Decreased [3H]spiperone binding in the anterior cingulate cortex in schizophrenia patients: an autoradiographic study. Neuroscience 109:709-716

Zavitsanou K, Mitsacos A, Giompres P, Kouvelas ED (1996): Changes in $[3 \mathrm{H}] \mathrm{AMPA}$ and $[3 \mathrm{H}]$ kainate binding in rat caudate-putamen and nucleus accumbens after 6-hydroxydopamine lesions of the medial forebrain bundle: an autoradiographic study. Brain Res 731:132-140

Zilles K (1990): Cortex. In Paxinos G (ed), The Human Nervous System. San Diego, Academic Press, pp 757-802 